\title{
DAMPAK PERUBAHAN LINGKUNGAN TERHADAP PERKEMBANGAN AKTIVITAS EKONOMI DAN KESEJAHTERAAN MASYARAKAT PESISIR DI KAWASAN SEGARA ANAKAN
}

\author{
Andrian Ramadhan dan Rani Hafsaridewi \\ Balai Besar Penelitian Sosial Ekonomi Kelautan dan Perikanan \\ Jl. KS. Tubun Petamburan VI Jakarta 10260 \\ Telp. (021) 53650162, Fax. (021)53650159 \\ Diterima 22 Februari 2012 - Disetujui 4 Juni 2012
}

\begin{abstract}
ABSTRAK
Penelitian bertujuan mengetahui pengaruh perubahan lingkungan Segara Anakan terhadap kehidupan sosial ekonomi masyarakat pesisir telah dilakukan pada bulan Mei - Juni 2011. Data yang dikumpulkan pada masyarakat di Desa Ujung Alang dan Klaces, Kecamatan Kampung Laut, Kabupaten Cilacap Provinsi Jawa Tengah dianalisis menggunakan analisis kesejahteraan rumah tangga berdasarkan indeks rumah tangga miskin menurut Badan Pusat Statistik (BPS) dan analisis deskriptif. Hasil penelitian menunjukkan bahwa sepanjang periode tahun 1980 - 2011 terjadi pergeseran aktivitas perekonomian masyarakat pesisir dari pemanfaatan sumberdaya perairan ke pemanfaatan sumberdaya daratan (sektor pertanian) seiring dengan bertambahnya wilayah lahan timbul. Pendapatan rata-rata riil sebesar Rp 335.078/kapita/bulan lebih tinggi dibandingkan dengan garis kemiskinan untuk wilayah pedesaan di Propinsi Jawa Tengah (Rp. 179.982 /kapita/bulan) yang ditetapkan oleh BPS. Meskipun demikian, pada periode tersebut terjadi penurunan pendapatan sebesar $59 \%$.
\end{abstract}

Kata kunci: perubahan lingkungan, kesejahteraan, masyarakat pesisir, Segara Anakan

\begin{abstract}
Impact of Environmental Changes to the Economic Activities and the Welfare of Coastal Communities in Segara Anakan. By: Andrian Ramadhan and Rani Hafsaridewi.
\end{abstract}

The study aims to determine the effect of environmental changes at Segara Anakan to the social and economic life of coastal communities have done in months May - June Data collected in the community in the village of Ujung Alang and Klaces, Sea Village District, the District Cilacap Central Java Province were analyzed using analysis of household welfare based index of poor households according to the Berau Statistic Central (BPS) and descriptive analysis. The results showed that during the period 1980 - 2011 there was a shift of economic activity from the coastal communities utilization of aquatic resources to the resource utilization of land (agricultural sector) along with increasing the area of land arise. The average real income of Rp 335,078/kapita/bulan higher than the poverty line for rural areas in Central Java (Rp 179,982 / capita / month) set by the BPS. However, in the period revenue decline of 59\%.

Keywords : environment, welfare, coastal, communities, Segara Anakan 


\section{PENDAHULUAN}

Salah satu karakteristik masyarakat nelayan adalah ketergantungan yang kuat terhadap lingkungan pesisir. Baik dan buruknya lingkungan pesisir akan berdampak secara langsung terhadap kehidupan mereka. Hal ini terkait dengan sumber daya perikanan yang ada diwilayah tersebut seperti udang, ikan, kepiting dan kekerangan yang rentan terhadap gangguan baik yang bersifat antropogenik atau naturalistik. Hal ini membentuk hubungan atau relasi timbal balik antara manusia dan alam. Salah satu fenomena yang dapat menjadi contoh cukup jelas adalah perubahan lingkungan yang terjadi di Kawasan Segara Anakan.

Segara Anakan merupakan laguna dengan wilayah perairan yang cukup luas pada masa lalu dimana pada tahun 1980 luasnya mencapai 3.852 ha. Namun seiring dengan waktu, wilayah perairan di kawasan ini terus mengalami penyempitan yaitu hanya sekitar 600 ha pada tahun 2000. Berkurangnya wilayah perairan berganti dengan zona-zona akresi yang akhirnya ditumbuhi dengan semak belukar dan mangrove. Meskipun demikian, luasan mangrove justru mengalami penurunan yang signifikan akibat adanya penebangan ilegal. Data dari Badan Pengelola Kawasan Segara Anakan (BPKSA), menunjukkan bahwa pada tahun 1984 luas mangrove mencapai 2.906 ha (Kompas, 2008). Jumlah tersebut pada tahun 1994 menyusut kembali sebesar 1.331 ha menjadi 1.575 ha. Penurunan terus terjadi dimana pada tahun 2005 hanya berkisar $834 \mathrm{Ha}$.

Kondisi di atas memberi pengaruh terhadap aktivitas masyarakat khususnya terkait dengan pemanfaatan sumberdaya perikanan. Sumber daya tersebut terus mengalami penurunan seiring dengan menyusutnya luas laguna dan mangrove diantaranya adalah udang, ikan dan kepiting. Akibatnya nelayan semakin sulit memenuhi kebutuhan hidupnya seiring dengan penurunan tersebut. Meskipun demikian, masyarakat sebagai sekumpulan manusia yang hidup berkelompok mampu belajar dari kondisi lingkungan hidupnya. Pembelajaran tersebut terakumulasi dan melahirkan kemampuan untuk beradaptasi. Hal ini pula yang terjadi pada masyarakat di Kawasan Segara Anakan yang beradaptasi dengan cara memanfaatkan lahan-lahan timbul untuk aktivitas pertanian. Tidak hanya itu mereka juga memanfaatkannya sebagai lahan perikanan budidaya meski masih berlangsung secara tradisional. Hal ini membawa suatu pertanyaan mengenai dampak dari perubahan lingkungan terhadap kondisi kesejahteraan masyarakat.

Untuk menjawab pertanyaan di atas maka diperlukan suatu kajian yang mengulas mengenai perkembangan aktivitas perekonomian yang berkembang serta pengaruhnya terhadap kesejahteraan masyarakat. Dengan demikian tujuan dari penelitian ini dapat dirumuskan sebagai berikut : (1) Mengetahui perkembangan aktivitas perekonomian yang terjadi seiring dengan perubahan lingkungan yang terjadi di Kawasan Segara Anakan; (2) Mengetahui tingkat kesejahteraan masyarakat yang sejalan dengan perkembangan aktivitas perekonomian.

\section{METODOLOGI}

\section{Waktu dan lokasi penelitian}

Penelitian dilakukan pada bulan Mei-Juni 2011 pada Desa Ujung Alang dan Desa Klaces, Kecamatan Kampung Laut, Kabupaten Cilacap, Jawa Tengah. Kedua desa tersebut dipilih karena sebagian besar penduduknya masih merupakan penduduk asli yang bertahan menjalankan profesinya sebagai nelayan pada wilayah perairan laguna Segara Anakan. Meskipun demikian, pada kedua desa ini pula terekam proses adaptasi masyarakat nelayan menjadi petani yang ditandai dengan proses pembukaan lahan-lahan pertanian pada zona tanah timbul yang ditumbuhi oleh semak dan mangrove. 


\section{Jenis dan Sumber Data}

Jenis data yang digunakan dalam penelitian ini adalah data sekunder dan data primer. Data sekunder didapatkan dari dokumentasi dan publikasi hasil pengkajian dan pendataan yang telah dilakukan. Data primer merupakan data yang akan dikumpulkan langsung dari masyarakat dan stakeholder lainnya yang ada di lapangan. Sumber data menurut Arikunto (1998:114) adalah subjek dari mana data dapat diperoleh. Secara lebih rinci sumber data dikategorikan dengan $3 \mathrm{P}$ yaitu person, place dan paper.

'Person' merupakan sumber data yang dapat memberikan data berupa jawaban lisan melalui wawancara atau jawaban tertulis melalui angket. 'Place' adalah sumber data yang menyajikan tampilan berupa keadaan diam dan bergerak. Keduanya merupakan objek untuk penggunaan metode observasi. Sedangkan 'paper' merupakan sumber data yang menyajikan tanda-tanda berupa huruf, angka, gambar, atau simbol-simbol lain. Beberapa sumber data sekunder yang dibutuhkan diantaranya adalah dari Badan Pengelola Kawasan Segara Anakan (BPKSA), BAPPEDA, BPN, kecamatan dan desa-desa yang ada dalam wilayah penelitian.

\section{Teknik pengumpulan data}

Teknik pengumpulan data pada dasarnya merupakan cara yang dilakukan untuk mendapatkan data yang diperlukan. Teknik pengumpulan data pada prakteknya dipengaruhi oleh jenis dan sumber data yang akan diambil. Oleh karena itu, pengumpulan data menggunakan lebih dari satu teknik pengumpulan data yang dilakukan pada penelitian ini. Berikut beberapa teknik yang digunakan:

\section{a. Wawancara}

Wawancara merupakan salah satu teknik yang dapat digunakan untuk menggali permasalahan yang ada dalam suatu wilayah serta sebagai alat yang tepat untuk mengetahui informasi secara mendalam dari responden
(Sugiyono, 2008). Secara definisi wawancara adalah dialog yang dilakukan dengan bertatap muka, yang bertujuan untuk memperoleh informasi faktual, untuk menaksir dan menilai kepribadian individu atau untuk tujuantujuan konseling/penyuluhan dan atau tujuan terapeutis (James P. Chaplin dalam Kartono, 1996 : 187). Oleh karena itu wawancara biasanya memerlukan waktu yang relatif lama dalam pelaksanaannya. Ada beberapa anggapan yang harus dianut menurut Sugiyono (2008) dalam melakukan kegiatan wawancara yaitu :

1. Bahwa subjek (responden) adalah orang yang paling tahu tentang dirinya sendiri

2. Bahwa apa yang dinyatakan oleh subjek kepada peneliti adalah benar dan dapat dipercaya

3. Bahwa interpretasi subjek tentang pertanyaan-pertanyaan yang diajukan peneliti kepadanya adalah sama dengan apa yang dimaksudkan oleh peneliti

Kegiatan wawancara ini secara lebih spesifik menggunakan wawancara secara terstruktur karena sudah cukup jelas informasi yang dibutuhkan dari responden. Untuk itu diperlukan alat bantu berupa pertanyaanpertanyaan tertulis agar informasi yang dibutuhkan tidak terlewat ditanyakan dan agar setiap pertanyaan memiliki arah tujuan yang jelas. Meskipun demikian dalam pelaksanaannya dapat dilakukan secara lebih fleksibel agar tidak terkesan kaku yang justru dapat menghambat keluarnya informasi yang sebenarnya.

\section{b. Kuesioner}

Pengumpulan data juga menggunakan kuesioner yang berisi seperangkat pertanyaan atau pertanyaan tertulis kepada responden untuk dijawab. Kuesioner merupakan teknik pengumpulan data yang efisien bila peneliti tahu dengan pasti variabel yang akan diukur dan tahu apa yang dapat diharapkan dari responden (Sugiyono,2008). Tipe pertanyaan dalam kuesioner secara teori dapat dibuat tertutup maupun terbuka tergantung kepada 
kebutuhan. Kuesioner dengan pertanyaan terbuka adalah kuesioner yang mengharapkan responden untuk menuliskan jawabannya berbentuk uraian tentang sesuatu hal. Sebaliknya pertanyaan tertutup adalah pertanyaan yang mengharapkan jawaban singkat atau mengharapkan responden untuk memilih salah satu alternatif jawaban dari setiap pertanyaan yang telah tersedia. Jenis kuesioner yang digunakan dalam penelitian ini menggunakan kedua tipe tersebut yang akan disesuaikan dengan kebutuhan analisis. Jumlah kuesioner yang dikumpulkan adalah sebanyak 50 kuesioner.

\section{c. Observasi}

Sutrisno Hadi (1986) dalam Sugiyono (2008) mengemukakan bahwa observasi merupakan suatu proses yang kompleks, suatu proses yang tersusun dari pelbagai proses biologis dan psikologis. Dua diantara yang terpenting adalah proses-proses pengamatan dan ingatan. Teknik ini digunakan karena penelitian berkenaan dengan perilaku manusia, proses kerja, gejala-gejala alam dan bila responden yang diamati tidak terlalu besar. Arikunto (2002) mengartikan observasi sebagai kegiatan pengamatan yang meliputi kegiatan pemusatan perhatian terhadap suatu objek dengan menggunakan seluruh teknik indra. Pada penelitian ini penggunaan teknik observasi adalah untuk melihat perkembangan kondisi yang terjadi di lapangan khususnya perubahan lingkungan akibat sedimentasi dan dampaknya terhadap aktivitas masyarakat yang tinggal di kawasan tersebut.

\section{d. Dokumentasi}

Berdasarkan penjabaran Arikunto (1998:236), metode ini adalah mencari data mengenai hal-hal atau variabel yang berupa catatan, transkrip, buku, surat kabar, majalah, prasasti, notulen rapat, legger, agenda dan sebagainya. Bila dilihat dari tingkat kesulitannya maka metode ini relatif mudah untuk dilakukan karena bila terjadi kesalahan tetap dapat dikoreksi mengingat sumber data adalah benda mati yang tidak berubah isinya.

\section{Teknik analisis data}

Analisis data merupakan proses penyederhanaan data ke dalam bentuk yang lebih mudah dipahami sehingga mudah untuk diinterpretasikan (Purwanto, 2007). Analisis data pada dasarnya juga merupakan alat yang digunakan untuk membedah permasalahan yang ada kemudian menyajikannya menjadi informasi yang jelas. Alat yang digunakan untuk menganalisis data disesuaikan dengan tujuan penelitian yaitu sebagai berikut :

\section{a. Analisis Data Deskriptif}

Analisis data secara deskriptif digunakan untuk menginterpretasikan data mentah yang berupa data primer dan sekunder menjadi suatu bentuk yang mudah dimengerti dan diterjemahkan (Wibisono, 2000). Data yang terkumpul dikategorisasikan, disusun ulang, dan dimanipulasi sehingga menyediakan informasi yang akan menjawab pertanyaan-pertanyaan yang dikemukakan. Analisis ini digunakan untuk mengeksplorasi perubahan lingkungan yang terjadi di Kawasan Segara Anakan dan dampaknya terhadap perekonomian masyarakat. Sehingga dapat dikatakan bahwa sifat analisis deskriptif yang digunakan adalah eksploratif. Penelitian deskriptif yang bersifat eksploratif menurut Arikunto (1998: 245) bertujuan untuk menggambarkan keadaan atau status fenomena.

\section{b. Analisis Tingkat Kesejahteraan}

Salah satu faktor yang penting untuk menilai dampak dari perubahan lingkungan terhadap masyarakat adalah tingkat kesejahteraan masyarakat. Standar kesejahteraan yang umum dipakai di Indonesia cukup bervariasi diantaranya adalah yang dikeluarkan oleh World Bank dan Badan Pusat Statistik (BPS). World Bank menetapkan ukuran nilai pendapatan USD 1/kapita/hari sebagai garis batas kemiskinan absolut. Kemiskinan 
absolut merujuk pada ketidakmampuan seseorang dalam mencukupi kebutuhan minimum hidupnya seperti pangan, sandang, kesehatan, perumahan dan pendidikan (BPS,2008). Standar kemiskinan menurut BPS dapat dilihat dari berbagai pendekatan. Beberapa diantaranya adalah dari pendekatan pendapatan dimana seseorang dikatakan miskin bila pendapatannya berada di bawah ambang batas tersebut. Secara nasional garis batas kemiskinan menurut BPS untuk daerah perkotaan pada tahun 2010 adalah Rp.232.989/kapita/bulan dan sedangkan untuk daerah pedesaan adalah Rp.192.354/ kapita/bulan. BPS juga mengeluarkan garis batas kemiskinan berdasarkan daerah dimana untuk Provinsi Jawa Tengah adalah Rp.205.606/kapita/bulan untuk daerah perkotaan dan Rp. 179.982/kapita/bulan untuk daerah pedesaan.

Pendekatan lainnya yang digunakan oleh BPS adalah pendekatan karakteristik rumah tangga. Model pendekatan ini telah digunakan dalam pelaksanaan kebijakan Bantuan Langsung Tunai (BLT) pada tahun 2005 sebagai kompensasi langsung atas kenaikan harga Bahan Bakar Minyak (BBM) kala itu. Pendekatan ini relatif berhasil memetakan rumah tangga miskin yang sebagai penerima bantuan meski tidak memuaskan semua pihak. Pendekatan ini menggunakan 14 variabel yang kemudian diberi skor dan diberi bobot. Bobotnya didasarkan kepada besarnya pengaruh dari setiap variabel terhadap kemiskinan. Berikut adalah ke 14 variabel tersebut :

1. Luas lantai bangunan tempat tinggal kurang dari $8 \mathrm{~m}^{2}$ per orang

2. Jenis lantai bangunan tempat tinggal terbuat dari tanah/bambu/kayu murahan

3. Jenis dinding tempat tinggal terbuat dari bambu/ rumbia/kayu berkualitas rendah/tembok tanpa diplester

4. Tidak memiliki fasilitas buang air besar/ bersama-sama dengan rumah tangga lain

5. Sumber penerangan rumah tangga tidak menggunakan listrik.

6. Sumber air minum berasal dari sumur/ mata air tidak terlindung/ sungai air

7. Bahan bakar untuk memasak sehari-hari adalah kayu bakar/ arang/ minyak

8. Hanya mengkonsumsi daging/ susu/ ayam satu kali dalam seminggu.

9. Hanya membeli satu stel pakaian baru dalam setahun.

10. Hanya sanggup makan sebanyak satu/ dua kali dalam sehari.

11. Tidak sanggup membayar biaya pengobatan di puskesmas/poliklinik.

12. Sumber penghasilan kepala rumah tangga adalah: petani dengan luas lahan 0,5 ha, buruh tani, nelayan, buruh bangunan, buruh perkebunan, atau pekejaan lainnya dengan pendapatan di bawah Rp. 600.000 per bulan.

13. Pendidikan tertinggi kepala kepala rumah tangga: tidak sekolah/tidak tamat SD/ hanya SD

14. Tidak memiliki tabungan barang yang mudah dijual dengan nilai Rp. 500.000, seperti: sepeda motor (kreditlnon kredit), emas, temak, kapal motor, ataubarang modal lainnya.

Pendekatan di atas digunakan pada penelitian ini untuk mengetahui tingkat kesejahteraan masyarakat khususnya masyarakat nelayan di Kawasan Segara Anakan. Variabel-variabel yang digunakan BPS dalam penentuan penerima BLT dalam penelitian ini dianggap memberi kontribusi yang sama terhadap tingkat kesejahteraan. Penelitian ini juga memodifikasi kriteria penilaian pada masing-masing variabel dan metode pemberian skor atau nilai sebagai berikut: 


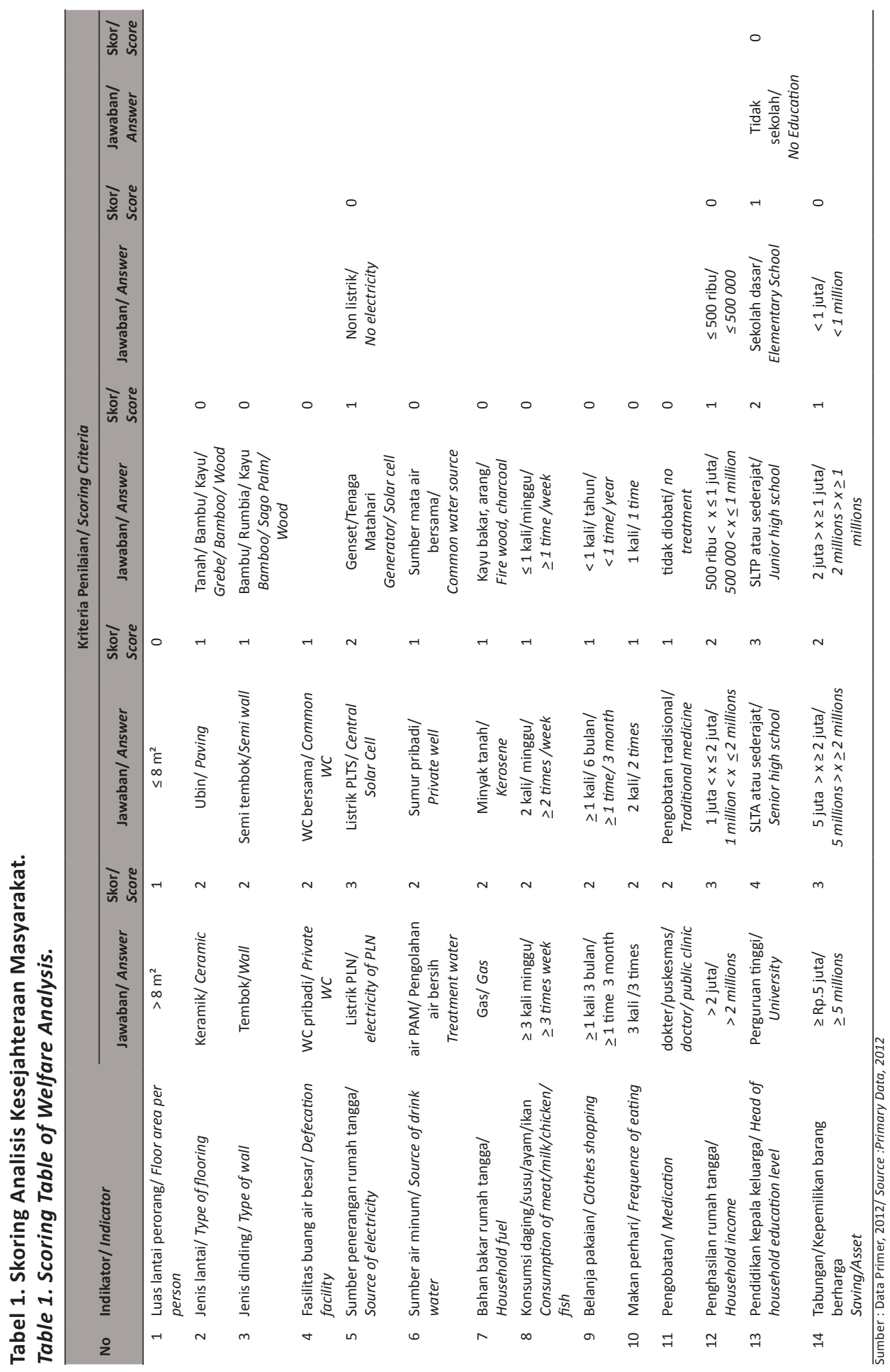


Hasil penilaian yang diperoleh dari Tabel 1 kemudian dikalkulasi menurut perhitungan berikut untuk mencari indeks kemiskinan :

\section{RM $=\Sigma \mathbf{W i} \mathbf{X i}$}

dimana:

$\mathrm{Wi}=$ Bobot variabel terpilih (bobot semua variabel sama yaitu $1 / 14$ sehingga $\Sigma \mathrm{Wi}=1$ / Variable value (all variables have a similar value $1 / 14, \Sigma W i=1$ )

$\mathrm{Xi}=$ Indeks nilai skoring variabel terpilih (selang nilai berkisar 0 sampai dengan 100 dimana nilai 0 menunjukkan situasi semakin miskin dan nilai 100 sebaliknya)/ Scoring index of selected variable (0 to 100 where 0 is an unfavorable answer)

$\mathrm{IRM}=$ Indeks rumah tangga miskin, dengan nilai antara 0 dan 100/ Household poverty index, 0 to 100

Sedangkan indeks nilai skor variabel dihitung dengan rumus berikut
$\mathrm{Xi}=\left(\mathrm{Ni} / \sum \mathrm{Ci}-1\right) \times 100$
$\mathrm{Ni}=\begin{aligned} & \text { Nilai skoring variabel ke-i/Scoring value } \\ & \text { of variable } i\end{aligned}$
$\mathrm{Ci}=$ Kriteria jawaban variabel ke-i/ Answer criteria of variable $i$

Setelah nilai total diperoleh, maka akan diketahui bahwa jumlah hasil akhir berkisar antara 0 dan 1. Agar didapatkan tingkat kesejahteraan dari tiap-tiap responden, maka nilai akhir tersebut dimasukkan kedalam 4 kelas sebagai berikut :

\section{HASIL DAN PEMBAHASAN}

\section{Gambaran Umum Lokasi}

Kawasan Segara Anakan berada pada wilayah pantai selatan Jawa Tengah yang tepatnya berada pada pada lintang 108046' 30,12"BT - 1090 03' 21,02" BT dan 7034' 29,42"LS - 7047' 32,39" LS (Mulyadi, 2009). Lokasi kawasan Segara Anakan terlindungi dari laut lepas selatan Jawa dengan sebuah pulau yang bernama Pulau Nusa Kambangan. Adanya pulau tersebut membuat keadaan perairan di Segara Anakan relatif tenang. Air laut Samudera Hindia masuk ke laguna ini melalui plawangan atau pintu selat Nusa Kambangan baik yang ada di ujung timur maupun di ujung barat. Pada Laguna Segara Anakan, air laut Samudera Hindia itu bertemu dengan air tawar yang ditumpahkan oleh sungai-sungai yang mengalir dari daratan tinggi di sebelah Utara, misalnya Sungai Citandui, Sungai Cibeureum, Sungai Cikonde, Sungai Cemeneng, dan lain-lain.

Kawasan Segara Anakan terletak pada di perbatasan antara Kabupaten Ciamis, Provinsi Jawa Barat dan Kabupaten Cilacap, Provinsi Jawa Tengah. Secara administratif Kawasan Segara Anakan berada dalam Kecamatan Kampung Laut yang terdiri dari empat desa yaitu Desa Ujungalang, Desa Ujunggagak, Desa Klaces dan Desa Panikel. Dari keempat desa tersebut, Desa Klaces merupakan desa termuda yang terbentuk pada tahun 2003. Sebelumnya desa tersebut masih merupakan bagian Desa Ujung Alang. Pemekaran desa tersebut dilakukan agar Kampung Laut memenuhi syarat sebagai satu wilayah kecamatan tersendiri.

Tabel 2. Kriteria Tingkat Kesejahteraan/Kemiskinan Masyarakat.

Table 2. Welfare Criteria of Community.

\begin{tabular}{ccc} 
Kelas/ Class & Rentang Nilai/ Value & Tingkat Kemiskinan/ Degree of Welfare \\
\hline I & $0-25$ & Sangat Miskin/ Very Poor \\
II & $26-50$ & Miskin/ Poor \\
III & $51-75$ & Kurang Sejahtera/ Less Welfare \\
IV & $76-100$ & Sejahtera/ Welfare \\
\hline
\end{tabular}

Sumber : Ramadhan, 2012/ Source :Ramadhan, 2012 


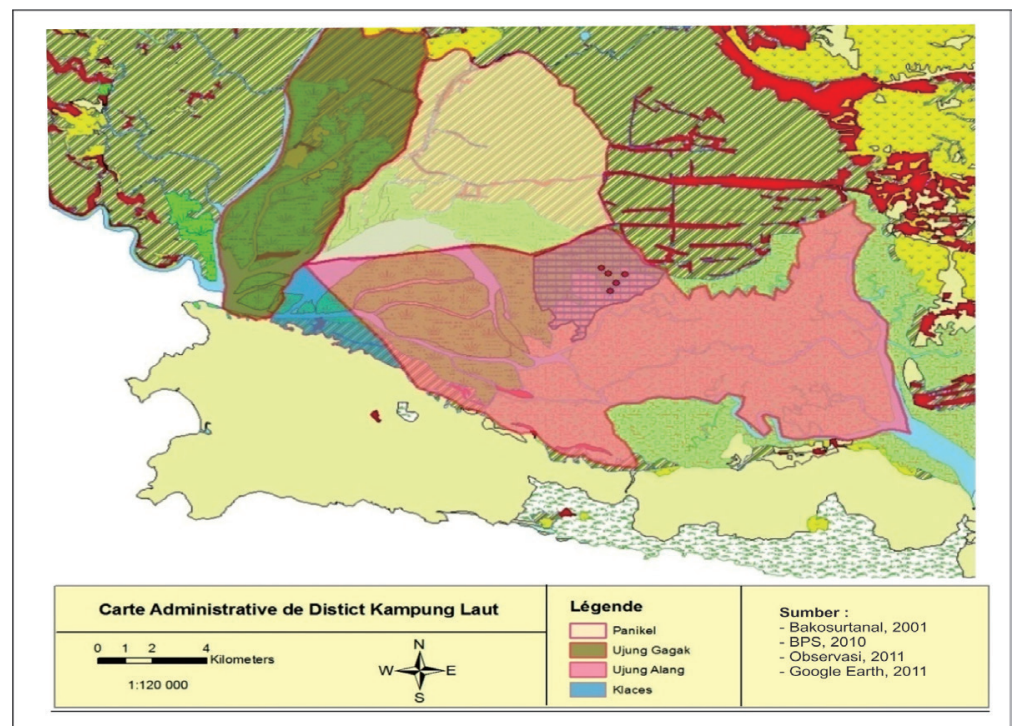

Gambar 1. Peta Administratif Kecamatan Kampung Laut.

Figure 1. Administrative Map of Kampung Laut Sub District.

Secara umum iklim pada Kabupaten Cilacap adalah iklim tropis dengan dua musim yaitu musim panas dan musim hujan. Berdasarkan data BPS (2010), musim panas dimulai pada bulan Juli dan berakhir sampai dengan bulan September. Tingkat maksimum curah hujan mencapai $612,3 \mathrm{~mm}$ dimana terjadi pada bulan Oktober, sedangkan tingkat minimum sebesar $1 \mathrm{~mm}$ terjadi pada bulan Agustus. Suhu rata-rata berkisar antara $27,1^{\circ} \mathrm{C}$ dengan suhu minimal $22.6^{\circ} \mathrm{C}$ dan suhu maksimal $31,9^{\circ} \mathrm{C}$ (BPS, 2010).

\section{Kependudukan dan Sosial Ekonomi}

Dalam periode 1990 - 2010 (Tabel 7), jumlah penduduk di Kecamatan Kampung Laut cenderung mengalami peningkatan sebesar, dengan pertumbuhan rata-rata penduduk sebesar 2,7 \% untuk periode 2000 - 2010. Rata-rata pertumbuhan penduduk di Kecamatan Segara Anakan disebabkan banyaknya pendatang, baik pindah secara resmi dan non resmi. Para pendatang tersebut bermukim dan menetap di wilayah tersebut karena semakin luasnya wilayah yang termanfaatkan sebagai lahan pertanian karena adanya sedimentasi.

Tabel 3. Perkembangan Jumlah Penduduk Kecamatan Kampung Laut, 1990-2010.

Table 3. Growth of Population in Kampung Laut Sub District, 1990-2010.

\begin{tabular}{|c|c|c|c|c|c|c|c|c|c|c|}
\hline \multirow{2}{*}{$\begin{array}{c}\text { Desa/ } \\
\text { Villages }\end{array}$} & \multicolumn{2}{|c|}{1990} & \multicolumn{2}{|c|}{1999} & \multicolumn{2}{|c|}{2000} & \multicolumn{2}{|c|}{2007} & \multicolumn{2}{|c|}{2010} \\
\hline & Jumlah & $\%$ & Jumlah & $\%$ & Jumlah & $\%$ & Jumlah & $\%$ & Jumlah & $\%$ \\
\hline Ujung gagak & 3,219 & 30.9 & 3,421 & 28.9 & 3,550 & 28.3 & 3,897 & 26.1 & 4,462 & 26.49 \\
\hline Ujung alang & 4,231 & 40.6 & 4,508 & 38.1 & 3,897 & 31.1 & 4,650 & 31.2 & 5,169 & 30.69 \\
\hline Klaces & - & - & - & & 794 & 6.3 & 1,247 & 8.4 & 1,393 & 8.27 \\
\hline Panikel & 2,961 & 28.5 & 3,906 & 330 & 4,293 & 34.3 & 5,113 & 34.3 & 5,817 & 34.54 \\
\hline Jumlah & 10,411 & 100 & 11,835 & 100 & 12,534 & 100 & 14,907 & 100 & 16,841 & 100 \\
\hline
\end{tabular}

Sumber: BPKSA dan BPS Kab Cilacap 2007 dan Monografi Kecamatan Kampung Laut 2010 (Ket : Tahun 1990 dan 1999 Desa Klaces masih bergabung dengan Desa Ujung Alang)/ Source: PKSA and BPS Regent Cilacap 2007 and Monograph of Kampung Laut Sub District 2010 (In 1990 and 1999, Village of Klaces was a partie of Ujung Alang) 
Tabel 4. Persentase Penduduk Menurut Status Penduduk Asli dan Pendatang tahun 2007. Table 4. Percentage of Population According to Native or Newcomer Status, 2007.

\begin{tabular}{lcc}
\hline \multirow{2}{*}{$\begin{array}{c}\text { Desa/ } \\
\text { Village }\end{array}$} & $\begin{array}{c}\text { Penduduk Asli/ } \\
\text { Native Resident }\end{array}$ & $\begin{array}{c}\text { Penduduk Pendatang/ } \\
\text { Newcomer }\end{array}$ \\
\cline { 2 - 3 } & $\mathbf{( \% )}$ & $(\%)$ \\
\hline Ujung Gagak & 79.0 & 21.0 \\
Ujung Alang & 71.6 & 28.4 \\
Klaces & 68.0 & 32.0 \\
Panikel & 56.9 & 43.1 \\
Total/ Total & $\mathbf{6 8 . 2}$ & $\mathbf{3 1 . 8}$ \\
\hline
\end{tabular}

Sumber : BPKSA dan BPS Kab Cilacap 2007/ Source :BPKSA and BPS of Cilacap Regency 2007

Sebagian besar penduduk Kecamatan Kampung Laut bekerja di sektor perikanan dan pertanian. Sektor perikanan selama ini menjadi kegiatan ekonomi utama dan dilakukan secara turun temurun. Sedangkan pertanian merupakan kegiatan ekonomi alternatif yang menjadi marak seiring dengan banyaknya lahan timbul di Kawasan segara Anakan. Pada realitas di lapangan banyak ditemui masyarakat yang berprofesi ganda yaitu sebagai nelayan dan juga petani.
Hal ini dilakukan secara simultan sehingga memberi keuntungan tersendiri bagi masyarakat. Masyarakat yang memiliki profesi ganda ini umumnya adalah warga asli Kampung Laut yang mendapatkan jatah lahan pertanian di daerah lahan timbul dimana diberikan oleh pemerintah desa setempat.

Tingkat pendidikan masyarakat di Kecamatan kampung Laut tergolong masih cukup rendah. Rendahnya tingkat pendidikan di Kecamatan Kampung Laut disebabkan

Tabel 5. Proporsi Mata Pencaharian Penduduk di Kecamatan Kampung Laut per Desa pada Tahun 2010.

Table 5. Proportion of Livelihood in the Kampung Laut Sub District by Village, 2010.

\begin{tabular}{|c|c|c|c|c|c|c|c|c|c|}
\hline \multirow[t]{2}{*}{ No } & \multirow{2}{*}{$\begin{array}{c}\text { Mata Pencaharian/ } \\
\text { Livelihood }\end{array}$} & \multicolumn{2}{|c|}{$\begin{array}{l}\text { Desa/ Village } \\
\text { Ujung Alang }\end{array}$} & \multicolumn{2}{|c|}{$\begin{array}{c}\text { Desa/ Village } \\
\text { Klaces }\end{array}$} & \multicolumn{2}{|c|}{$\begin{array}{c}\text { Desa/ Village } \\
\text { Panikel }\end{array}$} & \multicolumn{2}{|c|}{$\begin{array}{l}\text { Desa/ Village } \\
\text { Ujung Gagak }\end{array}$} \\
\hline & & Jumlah & $\%$ & Jumlah & $\%$ & Jumlah & $\%$ & Jumlah & $\%$ \\
\hline 1 & Nelayan/ Fisher & 770 & 42.52 & 20 & 5.18 & 192 & 5.23 & 1,525 & 58.50 \\
\hline 2 & Petani/ Farmers & 596 & 32.91 & 275 & 71.24 & 2,080 & 56.68 & 1,014 & 38.90 \\
\hline 3 & $\begin{array}{l}\text { Pengusaha/ } \\
\text { Enterpreuners }\end{array}$ & - & 0.00 & 4 & 1.04 & - & 0.00 & - & 0.00 \\
\hline 4 & $\begin{array}{l}\text { Buruh Industri/ } \\
\text { Industrial Workers }\end{array}$ & - & 0.00 & 4 & 1.04 & 407 & 11.09 & - & 0.00 \\
\hline 5 & $\begin{array}{l}\text { Buruh Bangunan/ } \\
\text { Construction laborers }\end{array}$ & 215 & 11.87 & 15 & 3.89 & 508 & 13.84 & 26 & 1.00 \\
\hline 6 & $\begin{array}{l}\text { Pedagang/ } \\
\text { Merchants }\end{array}$ & 52 & 2.87 & 50 & 12.95 & 169 & 4.60 & 20 & 0.77 \\
\hline 7 & $\begin{array}{l}\text { Pengangkutan/ } \\
\text { Bearers }\end{array}$ & - & 0.00 & 11 & 2.85 & 11 & 0.30 & 12 & 0.46 \\
\hline 8 & $\begin{array}{l}\text { PNS/TNI / Officials/ } \\
\text { Militaries }\end{array}$ & 8 & 0.44 & 6 & 1.55 & 8 & 0.22 & 10 & 0.38 \\
\hline 9 & Lainnya/ Others & 170 & 9.39 & 1 & 0.26 & 295 & 8.04 & - & 0.00 \\
\hline
\end{tabular}

Sumber : Laporan Monografi Kecamatan Kampung Laut 2010/ Source: Monograph of Kampung Laut Sub District, 2010. 
karena minimnya sarana prasarana pendidikan yang terdapat di Kecamatan Kampung Laut. Menurut BPS Kabupaten Cilacap 2010, jumlah SD sederajat sebanyak 9 buah, SLTP sederajat sebanyak 2 buah dan SLTA Sederajat sebanyak 1 buah.

Rendahnya tingkat pendidikan masyarakat memiliki implikasi logis pada ketergantungan masyarakat pada sumberdaya. Bagi masyarakat yang telah bertahun-tahun menjadi nelayan akan sulit mencari pekerjaan pengganti karena mungkin hanya itulah satu-satunya keahlian yang dimiliki. Sehingga meski sumberdaya ikan terus mengalami penurunan, mereka tetap melakukan penangkapan ikan. Laut menjadi satusatunya harapan sumber ekonomi rumah tangga mereka. Sebagian lainnya mencoba-coba aktivitas ekonomi dengan memanfaatkan lahan yang terbentuk akibat sedimentasi seperti untuk pertanian dan tambak perikanan. Namun karena keterbatasan keilmuan yang dimiliki, usaha mereka juga masih sangat tergantung pada alam (tradisional). Oleh karena tergantung pada alam, seringkali pula mereka mengalami kegagalan atau tidak mendapatkan hasil yang optimal.

\section{Perubahan Lingkungan dan Perkembangan Aktivitas Ekonomi Masyrakat}

Sedimentasi yang terus terjadi dengan laju yang sangat tinggi menimbulkan kekhawatiran akan kelestarian Laguna Segara Anakan. Berdasarkan tabel diketahui bahwa luas laguna mengalami penyusutan yang sangat hebat dalam kurun waktu 33 tahun terakhir dari 4.737 ha pada tahun 1978 menjadi hanya sebesar 673 ha pada tahun 2011. Hal itu pun setelah dilakukan pengerukan pada tahun 2003 sampai dengan tahun 2005 yang berhasil memperluas laguna menjadi 834 ha. Menurut perhitungan interpolasi kuadratik yang dilakukan oleh Parwati (2004), luas laguna Segara Anakan akan hilang pada tahun 2012 atau 34 tahun setelah pengamatan awal yang dilakukan pada tahun 1978.

Proses sedimentasi di Laguna Segara Anakan terjadi karena beberapa hal. Salah satunya karena penggunaan lahan yang tidak berkesinambungan (unsustainable land use) yang terjadi pada Daerah Aliran Sungai (DAS) Citanduy. Misalnya adalah konversi lahan menjadi ruang terbangun yang meningkat sebesar 2,18\% pada rentang tahun 1991 sampai dengan 2001. Peningkatan signifikan juga terjadi pada pemanfaatan lahan untuk kegiatan kebun campuran (7,2\%) (Dharmawan et al., 2004).

Tabel 6. Tingkat Pendidikan Kecamatan Kampung Laut Tahun, 2009.

Table 6. Level of Education in the Kampung Laut Sub District, 2009.

Tingkat Pendidikan/ Level of Education

Tidak Sekolah/ No Education

Tidak Tamat SD/ Do not pass the Primary School

Tamat SD/ Graduated the Primary School

Tamat SLTP/ Graduated the Secondary School

Tamat SLTA/ Graduated the Senior High School

D1/D2/D3/Akademi / Academy

Jumlah Orang/ Number Person

2,653

1,616

9,151

2,260

1,041

19

Keatas / Bachelor / Post Graduate 
Tabel 7. Perubahan Luas Laguna Segara Anakan, 1924-2011.

Table 7. Area Changes in Segara Anakan Lagoon, 1924-2011.

\begin{tabular}{cccc}
\hline Tahun/ Years & $\begin{array}{c}\text { Luas Laguna/ } \\
\text { Area (ha) }\end{array}$ & Tahun/ Years & $\begin{array}{c}\text { Luas Laguna/ } \\
\text { Area (ha) }\end{array}$ \\
\hline 1924 & 6,675 & 1984 & 2,906 \\
1940 & 6,445 & 1992 & 1,800 \\
1946 & 6,049 & 1994 & 1,575 \\
1961 & 5,412 & 2000 & 1,200 \\
1978 & 4,737 & 2003 & 600 \\
1980 & 3,852 & 2005 & 834 \\
1982 & 3,636 & 2008 & 750 \\
1983 & 3,206 & $2011^{*}$ & 673 \\
\hline
\end{tabular}

Sumber: ICLARM, PKSPL-IPB dan SACDP dalam Prayitno (2001), dan KPKSA (2009)/

Source : ICLARM, PKSPL-IPB and SACDP Cited by Prayitno (2001), and KPKSA (2009)

* nilai estimasi dihitung berdasarkan peta Google Earth, 2011/ estimation value based on Google Earth, 2011

Kondisi alam disekitar DAS Citanduy juga turut mempengaruhi kecepatan laju sedimentasi. Tingginya curah hujan pada daerah hulu yang mencapai 3.000-5.500 mm telah membawa partikel tanah yang berasal dari wilayah sekitarnya.
Begitu pula dengan daun-daunan kering yang terseret air masuk ke dalam aliran sungai. Bahkan pada saat musim kemarau sekali pun, curah hujan bagian hulu masih sebesar 200-300 $\mathrm{mm}$ perbulan.

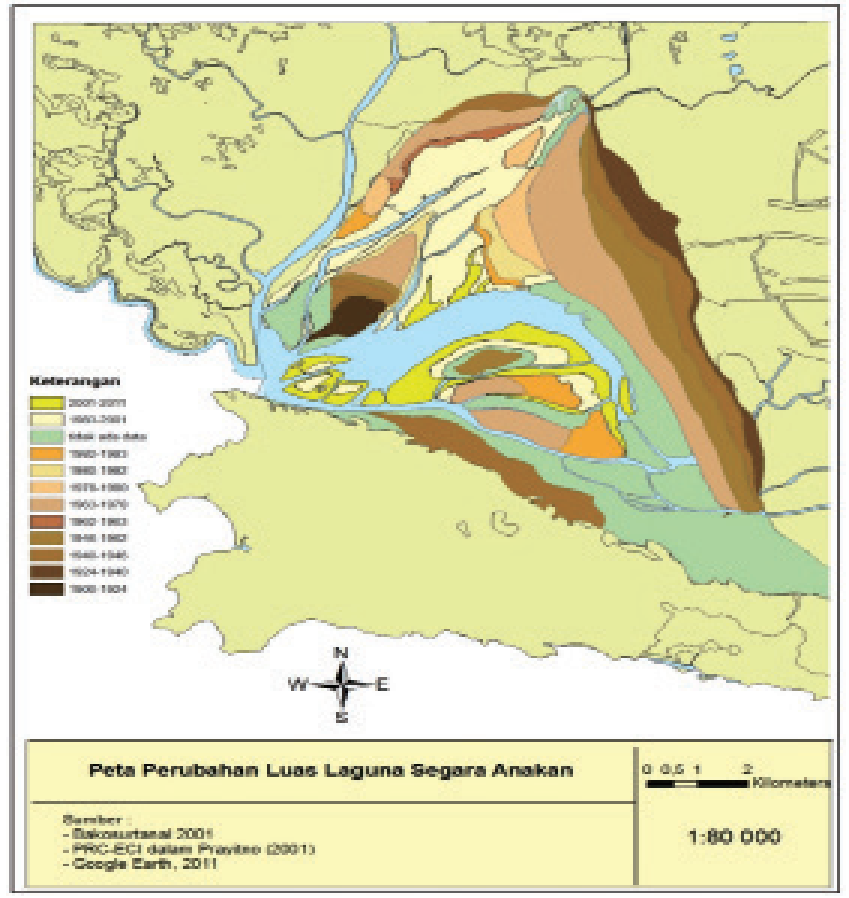

Gambar 2. Perubahan Luas Laguna Segara Anakan Akibat Sedimentasi Figure 2. Area Change of Segara Anakan Lagoon caused by Sedimentation Sumber : Berbagai sumber diolah, 2012/ Source : Processed from various source, 2012 
Seiring dengan perubahan lingkungan yang terjadi, manusia memiliki kemampuan untuk beradaptasi dengan lingkungan barunya. Tujuan dari adaptasi tersebut pada dasarnya adalah menghilangkan ketidaknyamanan dari perubahan yang terjadi. Menurut teori hambatan perilaku (behavior constraint theory), seseorang akan berusaha agar mampu mengontrol situasi agar tidak terjatuh pada situasi ketidakberdayaan yang dipelajari atau learned helplessness (Veitch dan Arkkelin, 1995 dalam Helmi, 1999). Besar atau sedikitnya kemampuan seseorang dalam melakukan kontrol inilah yang akhirnya akan menentukan kesuksesan seseorang dalam melakukan adaptasi.

Salah satu cara agar seseorang memiliki kemampuan untuk mengontrol adalah dengan cara memiliki privasi atas situasi tersebut (Giffort,1987 dalam Helmi, 1999). Sedangkan privasi sendiri memiliki tiga dimensi yang terdiri dari pengontrolan terhadap batas (boundary), upaya mendapatkan kondisi optimal dan proses multi mekanisme. Hal ini menjelaskan fenomena penguasaan lahan dimana upaya pembukaan lahan merupakan justifikasi penguasaan atas lahan yang ada di kawasan Segara Anakan. Batasnya ditentukan oleh kemampuan seseorang dalam melakukan pembersihan lahan. Hal tersebut kemudian menjadi dasar seseorang untuk mengelola lahan tersebut dengan kegiatan pertanian agar mendapatkan keuntungan yang optimal dari kepenguasaannya atas lahan tersebut. Situasi ini kemudian menjadi faktor pendorong berkembangnya aktivitas perekonomian dimasyarakat.

Selain bekerja di sektor perikanan, saat ini masyarakat juga banyak terlibat pada sektor pertanian. Kegiatan ini pada dasarnya memanfaatkan lahan-lahan timbul yang ditumbuhi oleh semak dan mangrove untuk "dibuka" agar menjadi sumber-sumber pendapatan baru masyarakat. Meski awalnya masyarakat tidak memiliki wawasan dalam bidang ini, namun seiring dengan waktu mereka mampu belajar khususnya dari para pendatang yang mengadu nasib untuk dapat memiliki lahan pertanian secara cuma-cuma. Pertengahan tahun 1980 an merupakan masa-masa kejayaan pertanian hampir diseluruh tanah timbul di Kawasan Segara Anakan. Hasil panen melimpah dan terlihat sangat menjanjikan sebagai sumber mata pencaharian baru untuk dipilih. Hal inilah yang kemudian membuat sebagian masyarakat nelayan memulai profesi bertani baik secara penuh maupun paruh waktu disela-sela kegiatan profesi utamanya sebagai nelayan.

Faktor alam tampaknya masih merupakan faktor dominan yang menentukan aktivitas ekonomi masyarakat kampung laut. Pada awal tahun 1990 an, banyak wilayah pertanian yang terendam oleh air asin. Hal ini menyebabkan gagal panen pada banyak tempat. Sampai dengan hari ini, fenomena tersebut masih terlihat jelas dengan banyaknya lahanlahan sawah yang tidak lagi dapat ditanami khususnya yang berada di daerah Batulawang sampai dengan daerah Pasuruan, Desa Ujung Alang. Pada wilayah lain yang berada pada posisi lebih tinggi dan dekat dengan aliran air sungai, kegiatan pertanian tumbuh dengan cukup baik.

Meski kegiatan pertanian mulai berkembang, mayoritas penduduk asli memilih tetap menjadi nelayan karena dinilai masih memberikan manfaat ekonomi yang lebih besar. Terlebih mereka telah mewarisi pola hidup dan kebiasaan nelayan yang berbeda jauh dengan pola hidup dan kebiasaan masyarakat petani. Sebagai contoh adalah kebiasaan mereka yang mendapatkan hasil dengan waktu yang cepat sedangkan petani harus menunggu lama untuk dapat menikmati hasilnya. Meskipun demikian, ada juga masyarakat nelayan yang memilih berganti profesi menjadi petani atau menjadikan pertanian sebagai sumber penghasilan tambahan. Hal ini terjadi khususnya pada masyarakat nelayan yang secara kebetulan menguasai lahan yang tidak terkena air laut sehingga masih terus dapat melakukan aktivitas pertani. Perkembangan mata pencaharian di kawasan ini disajikan pada Tabel 8. 
Tabel 8. Perkembangan Mata Pencaharian di Kecamatan Kampung Laut, 1980-2011. Tabel 8. Livelihood Development of Kampung Laut Sub District, 1980-2011.

\begin{tabular}{|c|c|c|c|c|c|c|c|c|c|}
\hline \multirow{2}{*}{ No } & \multirow{2}{*}{ Mata Pencaharian } & \multicolumn{2}{|c|}{ Tahun 1980} & \multicolumn{2}{|c|}{ Tahun 1990} & \multicolumn{2}{|c|}{ Tahun 2000} & \multicolumn{2}{|c|}{ Tahun 2010} \\
\hline & & Jml & $\%$ & Jml & $\%$ & $\mathrm{Jml}$ & $\%$ & Jml & $\%$ \\
\hline 1 & Nelayan/ Fisher & 3536 & 88.33 & 1,632 & 38.69 & 2,192 & 27.67 & 2,507 & 29.58 \\
\hline 2 & Petani/ Farmers & 238 & 5.95 & 1,276 & 30.25 & 3,926 & 49.56 & 3,965 & 46.79 \\
\hline 3 & $\begin{array}{l}\text { Pengusaha/ } \\
\text { Enterpreuners }\end{array}$ & - & - & 20 & 0.47 & 43 & 0.54 & 4 & 0.05 \\
\hline 4 & $\begin{array}{l}\text { Buruh Industri/ } \\
\text { Industrial Workers }\end{array}$ & - & - & 245 & 5.81 & 274 & 3.46 & 411 & 4.85 \\
\hline 5 & $\begin{array}{l}\text { Buruh Bangunan/ } \\
\text { Construction laborers }\end{array}$ & - & - & 191 & 4.53 & 431 & 5.44 & 764 & 9.02 \\
\hline 6 & Pedagang/ Merchants & 79 & 1.97 & 119 & 2.82 & 205 & 2.59 & 291 & 3.43 \\
\hline 7 & $\begin{array}{l}\text { Pengangkutan/ } \\
\text { Bearers }\end{array}$ & 70 & 1.72 & 66 & 1.56 & 128 & 1.61 & 34 & 0.40 \\
\hline 8 & $\begin{array}{l}\text { PNS/TNI / Officials/ } \\
\text { Militaries }\end{array}$ & 22 & 0.55 & 48 & 1.14 & 41 & 0.51 & 32 & 0.38 \\
\hline 9 & Lainnya/ Others & 58 & 1.45 & 621 & 14.72 & 681 & 8.62 & 466 & 5.50 \\
\hline
\end{tabular}

Sumber : LPM-ITB 1988 dan BPS Kab.Cilacap 2000 dalam Prayitno (diolah ,2001) dan Laporan Monografi Kecamatan Kampung Laut 2010.

Sources: LPM-ITB 1988 and 2000 BPS Kab.Cilacap in Prayitno (processed, 2001) and Sea Village Regency Monograph Report 2010

Sedangkan proporsi sumber mata pencaharian per desa pada tahun 2010 disajikan pada Tabel 9.

Selain kegiatan pertanian, perubahan lingkungan juga mendorong berkembangnya kegiatan budidaya perikanan. Banyak masyarakat yang beruji coba untuk membudidayakan udang, ikan bandeng dan juga kepiting. Namun demikian, hasil dari kegiatan budidaya tampaknya masih kurang menjanjikan. Hal ini menyebabkan masyarakat yang awalnya mencoba berbudidaya kemudian meninggalkan aktivitas tersebut karena dinilai gagal atau kurang menguntungkan. Permasalahan utamanya lebih disebabkan oleh faktor pengetahuan yang lemah tentang kegiatan budidaya perikanan. Hal ini terlihat dari penanganan kegiatan budidaya yang masih sangat tradisional. Contoh saja kualitas air didalam kolam pemeliharaan yang masih tidak diperhatikan oleh masyarakat. Begitu juga dengan pakan yang masih banyak menggantungkan pada pakan-pakan alami.

Tabel 9. Perkembangan Pendapatan Masyarakat Kampung Laut, 1980-2011.

Table 9. Development of Population Income in Kampung Laut Sub District, 1980-2011.

\begin{tabular}{cccr} 
Tahun/ Years & $\begin{array}{c}\text { Nilai Nominal/ } \\
\text { Nominal Value }\end{array}$ & $\begin{array}{c}\text { IHK }(\mathbf{2 0 0 0}=\mathbf{1 0 0}) / \\
\text { Consumer Price Index }\end{array}$ & Real Value \\
\hline 1980 & 179,000 & 12.62 & $1,418,384$ \\
1990 & 182,236 & 28.74 & 634,085 \\
2000 & $1,151,955$ & 100 & $1,151,955$ \\
2011 & $1,373,822$ & 235.99 & 582,152 \\
\hline
\end{tabular}

Sumber : Prayitno (2001), Bank Indonesia (2008), BPS (2011), dan data primer (2011)/

Source : Prayitno (2001), Bank Indonesia (2008), BPS (2011), and Primary Data (2011) 


\section{Analisis Kesejahteraan Masyarakat Akibat Perubahan Lingkungan}

Perubahan aktivitas ekonomi masyarakat sebagai respon dari perubahan lingkungan turut memberi dampak pada kesejahteraan masyarakat. Beberapa penelitian sebelumnya telah mengungkapkan keterkaitan antara perubahan lingkungan dengan beberapa indikator sosial ekonomi masyarakat. Salah satunya terhadap tingkat pendapatan masyarakat. Menurut catatan data Prayitno (2001), rata-rata pendapatan masyarakat secara nominal pada tahun 1980 adalah Rp. 179.000/bulan. Kenaikan juga terus tercatat pada tahun 1990 dan 2000 dimana nilainya secara berturut-turut adalah Rp. 182.236/bulan dan Rp. 1.151.955/bulan.

Berdasarkan hasil survei, ratarata pendapatan responden mencapai Rp. 1.369.262/bulan. Secara nominal pendapatan masyarakat memang terus meningkat. Namun nilai riil dari pendapatan tersebut belum tentu menunjukkan kenaikan. Untuk itu perlu dilakukan penyetaraan, yaitu dengan membagi nilai nominal tersebut dengan indeks harga konsumen yang menggunakan tahun dasar yang sama. Perbandingan nilai pendapatan masyarakat yang telah disetarakan tersaji pada Tabel 10.
Melihat perbandingan nilai pendapatan riil yang diperoleh masyarakat, dapat diketahui bahwa kenaikan nilai pendapatan nominal tidak dapat menggambarkan bahwa kehidupan masyarakat menjadi lebih baik. Pada kenyataannya, rata-rata pendapatan riil masyarakat saat ini hanya sebesar 40,9\% terhadap pendapatan riil pada tahun 1980 dan hanya 50,4\% terhadap pendapatan rill tahun 2000. Nilai ini bahkan lebih kecil dari pendapatan riil masyarakat pada tahun 1990, dimana pada waktu tersebut masyarakat yang mengalami gagal panen hebat akibat masuknya air asin ke dalam sebagian besar lahan sawah warga. Dengan demikian dapat dikatakan bahwa tidak terjadi perbaikan kesejahteraan di masyarakat bahkan lebih buruk bila dilihat dari tingkat pendapatan riil dimasyarakat.

Pengukuran tingkat kesejahteraan seringkali juga dilakukan terhadap standar yang dikeluarkan badan internasional seperti world bank dimana seseorang dikatakan miskin bila memiliki pendapatan kurang dari $1 \$$ perkapita per hari. Berdasarkan nilai tukar mata uang rupiah terhadap 1 dollar US pada tahun 2011 sebesar Rp. 8.500, di ketahui bahwa rata-rata pendapatan responden perkapita pada tahun 2011 adalah

\section{Tabel 10. Rata-Rata Pendapatan Responden Nelayan yang Memiliki Sumber Mata Pencaharian Tambahan.}

Table 10. Average of Fishers Income Who Have an Additional Income.

\begin{tabular}{|c|c|c|c|c|c|}
\hline Mata pencaharian/Livelihood & $\begin{array}{l}\text { ¿ sampel/ } \\
\text { Sample }\end{array}$ & $\%$ & $\begin{array}{l}\text { Pendapatan Utama } \\
\text { Perbulan/ Main } \\
\text { Income Per Month }\end{array}$ & $\begin{array}{c}\text { Pendapatan } \\
\text { Tambahan } \\
\text { Perbulan/ } \\
\text { Additional } \\
\text { Income Per } \\
\text { Month }\end{array}$ & $\begin{array}{c}\text { Total } \\
\text { Pendapatan } \\
\text { Perbulan/ } \\
\text { Total Income } \\
\text { Per Month }\end{array}$ \\
\hline Nelayan + Petani/ Fisher + Farmer & 7 & 63.6 & $1,617,786$ & 259,929 & $1,872,950$ \\
\hline $\begin{array}{l}\text { Nelayan + Pembudidaya Perikan/ } \\
\text { Fisher + Aquaculturist }\end{array}$ & 1 & 9.1 & 727,500 & 516,000 & $1,244,100$ \\
\hline $\begin{array}{l}\text { Nelayan+Petani+Pedagang/ Fisher } \\
\text { + Farmer+Merchant }\end{array}$ & 2 & 18.2 & $1,500,000$ & 761,750 & $2,835,000$ \\
\hline $\begin{array}{l}\text { Nelayan+Petani+Pembudidaya } \\
\text { Perikanan/ Fisher + Farmer+ } \\
\text { Aquaculturist }\end{array}$ & 1 & 9.1 & 830,000 & 31,250 & 861,250 \\
\hline Total/ Total & 11 & 100 & $1,443,818$ & 353,659 & $1,854,636$ \\
\hline
\end{tabular}

Sumber : Data primer diolah/Source: Processed from primary data, 2012 
Rp.11.169/perkapita/hari atau 1.3\$ US perhari. Berdasarkan ukuran ini maka masyarakat di Kampung Laut saat ini masih diatas batas ambang kemiskinan. Sedangkan bila menggunakan standar garis kemiskinan BPS tahun 2010 untuk daerah pedesaan pada wilayah Jawa Tengah sebesar Rp. 179.982 /kapita/bulan, maka diketahui bahwa rata-rata pendapatan masyarakat berada diatas garis batas tersebut. Rata-rata pendapatan responden atas hasil survei adalah sebesar Rp. 335.078/perkapita/ bulan. Dengan demikian dapat dikatakan meskipun pendapatan riil masyarakat terus menurun, akan tetapi tidak sampai melewati garis kemiskinan yang digunakan baik oleh World Bank maupun BPS.

Berdasarkan data, kita dapat pula melihat kesejahteraan rumah tangga berdasarkan variasi mata pencaharian responden yang terbagi atas rumah tangga nelayan (26\%), rumah tangga petani (22\%), rumah tangga pembudidaya (20\%), rumah tangga nelayan yang memiliki lebih dari satu mata pencaharian (22\%) dan rumah tangga non nelayan yang memiliki lebih dari satu mata pencaharian (10\%). Hal ini dilakukan khususnya untuk mengetahui perbedaan kesejahteraan antara masyarakat yang masih mempertahankan sumber pendapatannya sebagai nelayan, masyarakat yang memilih pekerjaan lain sebagai sumber pendapatan keluarga, masyarakat nelayan yang memiliki pendapatan tambahan dan masyarakat yang memilih pekerjaan lain sekaligus memiliki sumber pendapatan lain pada saat yang bersamaan.

Bila dilihat dari besaran pendapatan keluarga, maka yang terbesar adalah masyarakat nelayan yang memiliki pendapatan tambahan yaitu sebesar Rp.1.854.636. Sedangkan masyarakat yang hanya bekerja sebagai nelayan pendapatannya lebih rendah yaitu sebesar Rp. 1.328.692, meskipun masih lebih tinggi bila dibandingkan dengan rumah tangga yang hanya bekerja sebagai petani yaitu sebesar Rp. 1.086.142/bulan. Begitu pula bila dibandingkan dengan pendapatan rumah tangga non nelayan yang memiliki pendapatan tambahan yaitu sebesar Rp. 1.162.260. Rumah tangga yang memiliki mata pencaharian hanya sebagai pembudidaya ikan memiliki pendapatan yang paling rendah yaitu Rp. 935.444/bulan.

Diantara masyarakat nelayan yang memiliki sumber pendapatan tambahan, sebanyak $81,8 \%$ merupakan masyarakat yang merangkap sebagai petani dan memiliki lahan pertanian aktif. Kondisi ini menunjukkan bahwa kegiatan pertanian yang berasal dari pemanfaatan lahan timbul, memberikan hasil yang nyata bagi masyarakat nelayan. Namun sayangnya tidak semua nelayan memiliki lahan pertanian untuk digarap. Bagi sebagian masyarakat nelayan, membuka lahan-lahan kosong menyita waktu dan tenaga yang cukup banyak. Selain itu mereka merasa tidak terbiasa dengan kegiatan pertanian, sehingga menurunkan minat dalam membuka lahan. Ada pula mereka yang memiliki lahan, akan tetapi lahannya terendam oleh air asin semenjak awal tahun 1990-an sehingga tidak lagi dapat digunakan untuk kegiatan pertanian. Sebagian lainnya sudah menjual lahan-lahan yang telah dibuka (ditrukah) kepada para pendatang karena merasa tidak sabar dengan usaha pertanian yang membutuhkan waktu relatif lama. Penjualan lahan juga dilakukan seiring dengan desakan kebutuhan keluarga baik pada saat kebutuhan insidental seperti nikahan atau pada saat musim paceklik.

Sebagaimana terlihat pada Tabel 9 sumbangan pendapatan nelayan juga berasal dari kegiatan budidaya perikanan. Namun demikian, sangat sulit ditemukan masyarakat nelayan yang secara aktif dan berkelanjutan dalam beraktivitas budidaya ikan. Hal ini dikarenakan minimnya pengetahuan masyarakat tentang tata cara berbudidaya, sehingga banyak diantara mereka yang mengalami kegagalan. Jenis budidaya perikanan yang sering dicoba oleh nelayan dalam beberapa tahun terakhir adalah budidaya kepiting dengan menggunakan sistem keramba tancap atau kolam yang dikelilingi dengan menggunakan waring. Kegagalan umumnya terjadi karena banyaknya 
kepiting yang dapat melarikan diri, sehingga hasil yang didapat tidak sesuai dengan ongkos produksi dan waktu yang dikorbankan.

Selain melalui pendekatan pendapatan, tingkat kesejahteraan juga bisa dilihat dari karakteristik rumah tangga dimana menurut BPS (2008) terwakili oleh 14 variabel yang menjadi indikator (Lampiran). Setelah dilakukan pengolahan, maka diketahui bahwa dari responden yang di survei tidak ditemukan responden yang masuk dalam kategori tidak sejahtera atau miskin. Akan tetapi jumlah persentase masyarakat yang termasuk dalam kategori kurang sejahtera cukup banyak yaitu mencapai $46 \%$. Sedangkan sisanya terbagi menjadi masyarakat yang cukup sejahtera sebesar $50 \%$ dan hanya $4 \%$ yang dapat digolongkan dalam kategori sejahtera.

Analisis kesejahteraan dengan pendekatan karakteristik rumah tangga menunjukkan bahwa faktor pendapatan saja tidak dapat menggambarkan secara utuh kondisi kesejahteraan rumah tangga. Hal ini terbukti dari kondisi rumah tangga nelayan yang ternyata secara persentase lebih banyak yang berada pada kategori kurang sejahtera bila dibandingkan dengan kelompok yang lainnya. Penyebab hal ini salah satunya adalah tempat tinggal responden yang secara umum lebih baik. Selain itu, nelayan juga relatif tercukupi angka gizinya karena konsumsi ikan yang lebih tinggi bila dibandingkan dengan yang lainnya. Tingginya konsumsi ikan disebabkan oleh budaya masyarakat serta ketersediaan sumberdaya yang cukup. Nelayan pada umumnya mencukupi kebutuhan akan ikan tidak dari membeli tetapi dari hasil tangkapan yang tidak dijual. Sementara kerang-kerangan ketersediaannya juga cukup melimpah sehingga jarang para nelayan membeli dari para pengumpul kerang. Kondisi tersebut membuat masyarakat memiliki kondisi baik dalam hal keamanan pangan khususnya kecukupan protein yang menjadi salah satu indikator utama kemiskinan.

Tabel 11. Kategori Tingkat Kesejahteraan Responden.

Table 11. Level of Respondent Welfare.

\begin{tabular}{|c|c|c|c|c|c|c|}
\hline \multirow[b]{2}{*}{$\begin{array}{l}\text { Kelompok Mata } \\
\text { Pencaharian/ } \\
\text { livelihoods }\end{array}$} & \multicolumn{4}{|c|}{ Kategori/Category } & \multirow[b]{2}{*}{$\begin{array}{c}\sum \\
\text { Sampel/ } \\
\sum \text { Sample }\end{array}$} & \multirow{2}{*}{$\begin{array}{l}\text { \% Terhadap } \\
\text { Total } \\
\text { Responden/ } \\
\text { \% Toward } \\
\text { Total } \\
\text { Respondent }\end{array}$} \\
\hline & $\begin{array}{l}\text { Sangat } \\
\text { Miskin/ } \\
\text { poor (\%) }\end{array}$ & $\begin{array}{c}\text { Miskin/ } \\
\text { Poor } \\
(\%)\end{array}$ & $\begin{array}{c}\text { Kurang } \\
\text { sejahtera/ } \\
\text { Less Welfare } \\
(\%)\end{array}$ & $\begin{array}{c}\text { Sejahtera/ } \\
\text { Welfare } \\
\text { (\%) }\end{array}$ & & \\
\hline Nelayan / Fishers & 0 & 15.4 & 84.6 & 0 & 13 & 26 \\
\hline $\begin{array}{l}\text { Petani/pembudidya } \\
\text { ikan yang memiliki } \\
\text { mata pencaharian } \\
\text { tambahan/ Fishers with } \\
\text { additional income }\end{array}$ & 0 & 27.3 & 63.6 & 9.1 & 11 & 22 \\
\hline Petani/ Farmers & 0 & 54.5 & 45.5 & 0 & 11 & 22 \\
\hline $\begin{array}{l}\text { Pembudidaya } \\
\text { Perikanan/ } \\
\text { Aquaculturist }\end{array}$ & 0 & 90 & 10 & 0 & 10 & 20 \\
\hline $\begin{array}{l}\text { Farmer or aquaculturist } \\
\text { with additional income }\end{array}$ & 0 & 60 & 40 & 0 & 5 & 10 \\
\hline Total/ Total & 0 & 46 & 50 & 4 & 50 & 100 \\
\hline
\end{tabular}

Sumber: Data primer diolah/ Source : Processed from primary data, 2012 


\section{KESIMPULAN DAN IMPLIKASI KEBIJAKAN}

\section{Kesimpulan}

Peristiwa yang terjadi di Kawasan Segara Anakan memberi informasi penting bagi pengelolaan wilayah pesisir khususnya kebijakan di sektor kelautan dan perikanan. Meskipun situasi pada setiap wilayah bersifat unik dengan keciriannya masingmasing, akan tetapi ada nilai-nilai yang menjadi pembelajaran secara umum. Beberapa hal penting yang dapat diambil dari penelitian ini adalah :

1. Kelestarian Kawasan Segara Anakan terancam akibat laju sedimentasi yang tinggi. Sedimentasi menyebabkan perubahan lingkungan yang besar dan berdampak besar bagi sumber daya perikanan dan kelautan. Hal ini membuat masyarakat harus beradaptasi dan mencari sumber-sumber mata pencaharian baru seperti pertanian yang sangat potensial untuk dikembangkan pada wilayah-wilayah lahan timbul.

2. Pendapatan masyarakat secara umum mengalami penurunan dari waktu ke waktu. Perubahan lingkungan membuat hasil yang diperoleh semakin menurun. Meski secara nominal mengalami kenaikan, akan tetapi hal tersebut tidak sebanding dengan laju inflasi yang terjadi. Akibatnya secara riil, nilai yang diperoleh semakin sedikit.

3. Tingkat kesejahteraan masyarakat secara umum masih kurang sejahtera meski tidak ditemukan rumah tangga yang miskin sebagaimana kriteria yang ditetapkan BPS. Secara lebih spesifik juga diketahui bahwa sumberdaya perikanan di Kawasan Segara Anakan masih memberi pengaruh penting terhadap tingkat kesejahteraan masyarakat. Hal ini terbukti dari tingkat kesejahteraan masyarakat berdasarkan mata pencaharian dimana masyarakat nelayan memiliki tingkat kesejahteraan yang relatif lebih baik.

\section{Implikasi Kebijakan}

Laguna Segara Anakan yang terus mengalami pendangkalan perlu dikeruk kembali agar eksistensinya terus dapat dipertahankan. Mengingat keberadaan laguna sangat penting artinya secara ekologi dan secara ekonomi khususnya bagi masyarakat, penyelamatan eksistensi laguna berarti dua hal yaitu menyelamatkan biodiversitas sekaligus menjamin ketersediaan sumber daya yang menggerakkan perekonomian masyarakat. Selain pengerukan, penyelamatan dapat dilakukan dengan menerapkan kebijakan pemanfaatan lahan yang berkelanjutan khususnya pada wilayah-wilayah disekitar DAS yang bermuara pada Laguna Segara Anakan.

Pada sisi lain masyarakat nelayan memiliki kemampuan untuk memanfaatkan sumber daya yang ada di sekeliling mereka sebagai alternatif mata pencaharian. Salah satunya adalah pemanfaatan lahan sebagai lahan pertanian. Meski membutuhkan waktu, masyarakat nelayan terbukti mampu beradaptasi dengan kondisi lingkungan yang baru. Kenyataan ini penting untuk pengembangan mata pencaharian alternatif mengingat tekanan sumber daya pesisir yang semakin besar. Pengembangan ini juga dapat mengurangi ketergantungan masyarakat nelayan terhadap lingkungan pesisir. Secara jangka menengah dan panjang, berkurangnya ketergantungan masyarakat terhadap sumber daya pesisir diharapkan dapat membatasi jumlah pengakses sumber daya. Hal ini penting dilakukan untuk menjamin keseimbangan antara jumlah pemanfaatan dan kapasitas lingkungan untuk memulihkan diri sehingga keberlanjutan sumber daya dapat terjamin.

\section{DAFTAR PUSTAKA}

Ardli R E dan Wolff M. 2008. Land use and land cover change affecting habitat distribution in the Segara Anakan Lagoon. Java. Indonesia. Reg Environ Change (2009) 9:235-243 (c) Springer-Verlag 2008. 
Arikunto, S. 1998. Prosedur Penelitian : Suatu Pendekatan Praktek. Rineka Cipta. Jakarta. 2002. Prosedur Penelitian : Suatu Pendekatan Praktek. Rineka Cipta. Jakarta.

Badan Pusat Statistik. 2008. Analisis dan Penghitungan Tingkat Kemiskinan . Jakarta.

Badan Pusat Statistik. 2011. Berita Remi Statistik. Perkembangan indeks harga konsumen/ inflasi no. 25/05/th XV, 2 mei 2011.

Badan Pusat Statistik. 2010. Perkembangan Beberapa Indikator Utama Sosial Ekonomi Indonesia. Jakarta.

Badan Pusat Statistik Kab Cilacap 2007. Kabupaten Cilacap dalam Angka 2007. Cilacap.

Dharmawan, Kerisnamurthi, Tanjung, Tomny, Prasetyo, Fausia, Prasodjo, Suharno, Indaryanti, Mardiyaningsih, 2004. Desentralilasi Pengelolaan dan Sistem Tata Pemerintahan Sumberdaya alam DAS Citanduy. Pusat Studi Pembangunan. Institut Pertanian Bogor dan Partnership for Governance Reform in Indonesia. UNDP. Bogor

Helmi, 1999. Beberapa Teori Psikologi Lingkungan. Buletin Psikologi Tahun VIII No.2 ISSN: 0854-7108. Jakarta.

Hidayat dan Hirschmann, 2009. Surat dari Jerman : Mencegah Anak Laut Tenggelam. Gatra edisi 39. 12 Agustus 2009. Jakarta.

Kartono, K. 1996. Pengantar Metodologi Riset Sosial. Mandar Maju. Bandung.
Kompas. 2008. Luas Segara Anakan Tinggal Kurang dari 800 Hektar. http://internasional. kompas.com/read/2008/12/14/17274064/ Luas.Segara.Anakan.Tinggal.Kurang. dari.800. Hektar.

Kecamatan Kampung Laut. 2010. Monografi Kecamatan Kampung Laut 2010. Cilacap.

Mulyadi, A. 2009. Laguna Segara Anakan Sebagai Objek Studi Lapangan Geografi. Seminar Pendidikan Nasional Geografi. Pertemuan IImiah Daerah (PITDA) Ikatan Geograf Indonesia (IGI) Wilayah Jawa Barat.

Parwati. 2004. Investarisasi dan Prediksi Dinamika Kawasan Pesisir Segara Anakan Menggunakan Teknologi Penginderaan Jauh. Makalah Pengantar Falsafah Sains Program Pasca Sarjana. Institut Pertanian Bogor. Bogor.

Prayitno. 2001. Perubahan Sosial Ekonomi Masyarakat Desa Pantai Akibat Perubahan Ekosistem Pantai: Studi Kasus Di Kawasan Segara Anakan Cilacap (Tesis). Program Pasca Sarjana Universitas Gadjah Mada. Yogyakarta.

Ramadhan, 2012. Dampak Perubahan Lingkungan di Kawasan Segara Anakan Terhadap Ekonomi Masyarakat Kampung Laut (Tesis). Program Pasca Sarjana Magister Pembangunan Wilayah dan Kota. Universitas Diponegoro. Semarang.

Sugiyono. 2008. Metode Penelitian Kuantitatif Kualitatif dan R\&D (edisi pertama). Alfabeta. Bandung. 


\section{Lampiran/ Appendix}

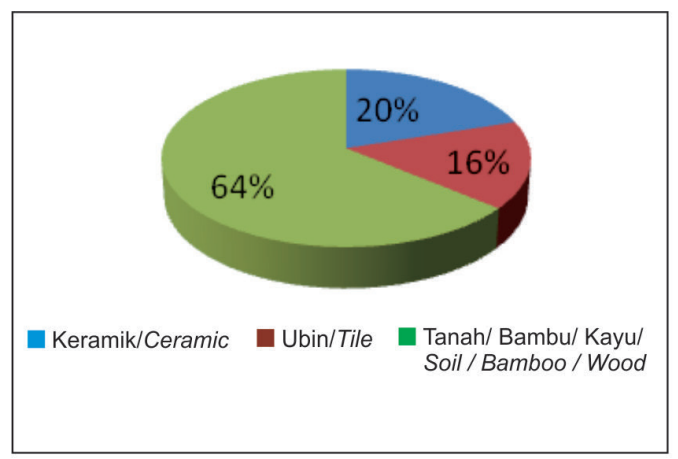

Gambar 1. Jenis Lantai Rumah

Figure 1. Type of House Floor

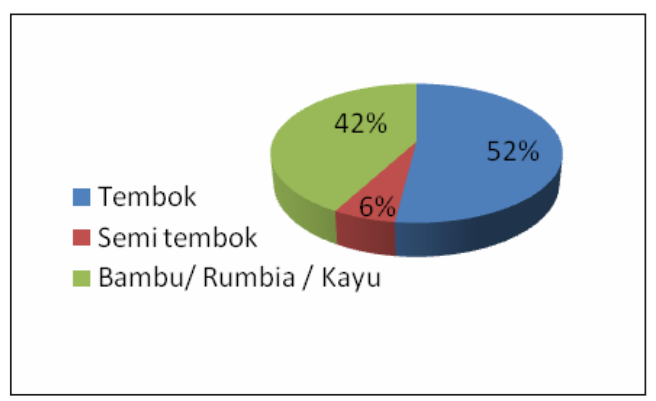

Gambar 3. Jenis Dinding Rumah

Figure 3. Type of House Wall

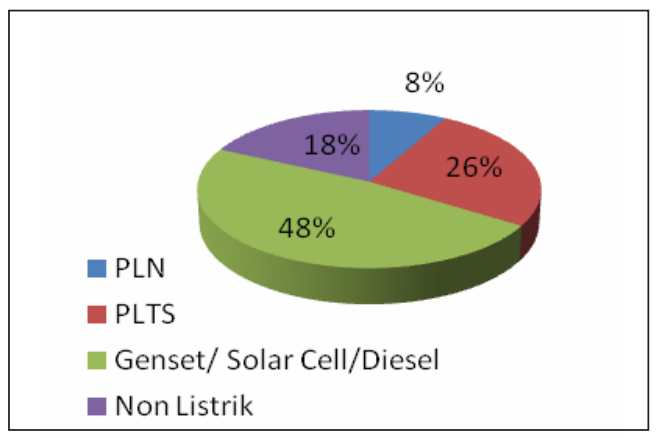

Gambar 5. Sumber Penerangan Rumah Tangga

Figure 5. Source of Lighting

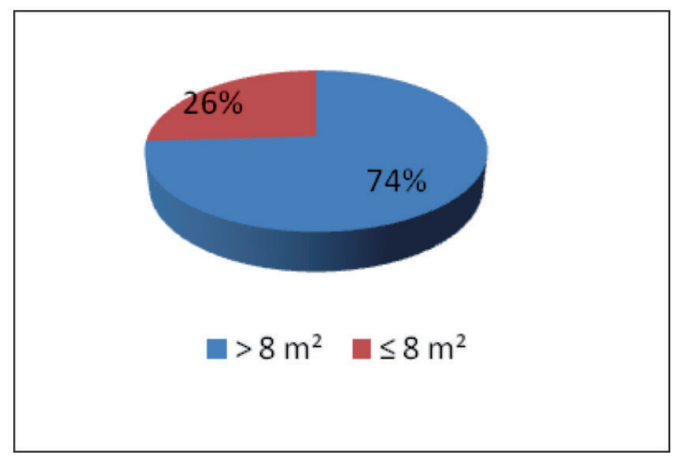

Gambar 2. Luas lantai per jiwa Figure 2. Floor Area Per Capita

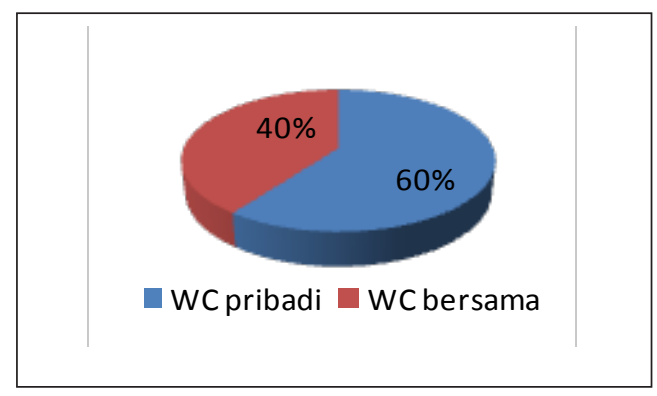

Gambar 4. Fasilitas Buang Air Besar Figure 4. Toilet Facilities

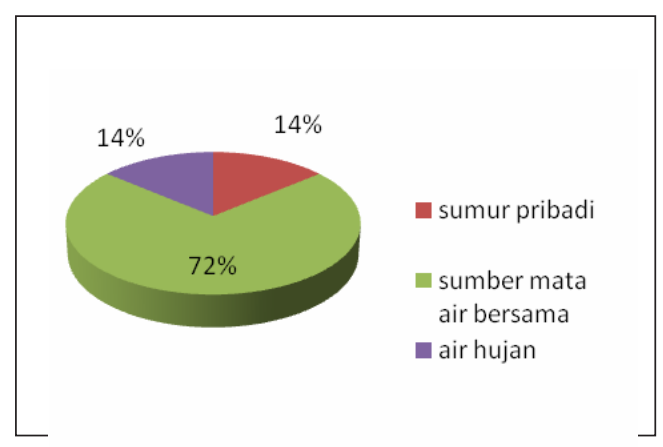

Gambar 6. Sumber Air Minum Rumah Tangga

Figure 6. Source of Water 


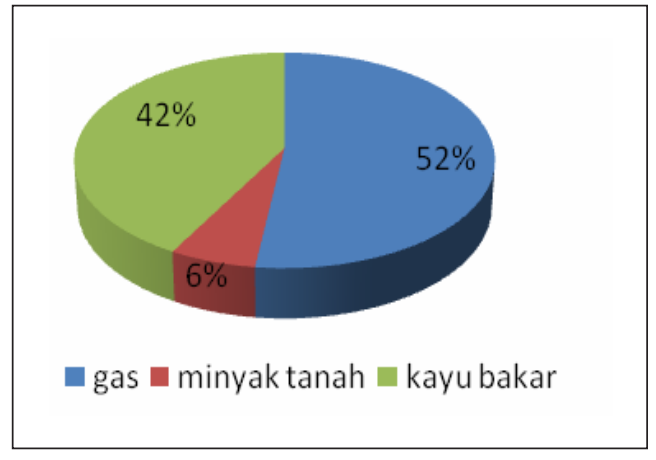

Gambar 7. Bahan Bakar Rumah Tangga

Figure 7. Source of Domestic Fuel

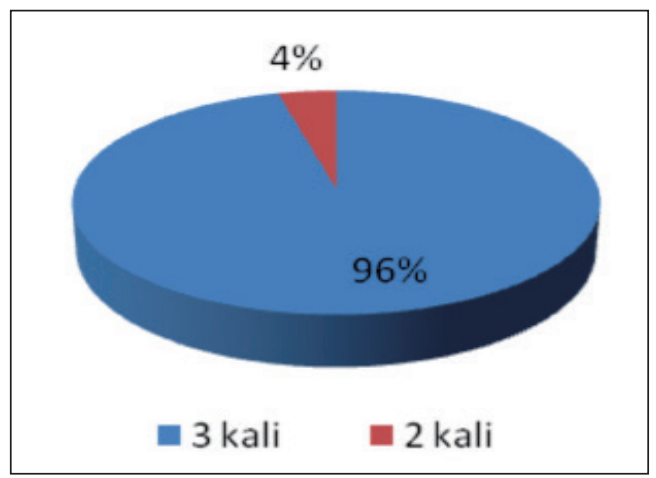

Gambar 9. Frekuensi Makan Per Hari

Figure 9. Frequency of Eat per Day

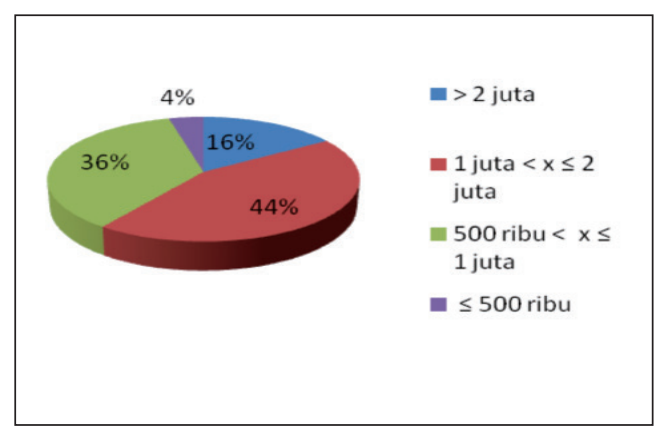

Gambar 11. Penghasilan Rumah Tangga/ Bulan

Figure 11. Household Income/Month

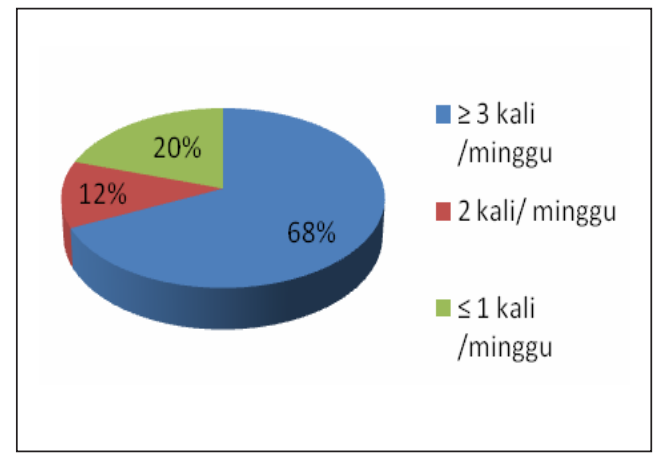

Gambar 8. Konsumsi daging/Ayam/Susu/ Ikan

Figure 8. Consumtion of Meat/Chicken/ Fish

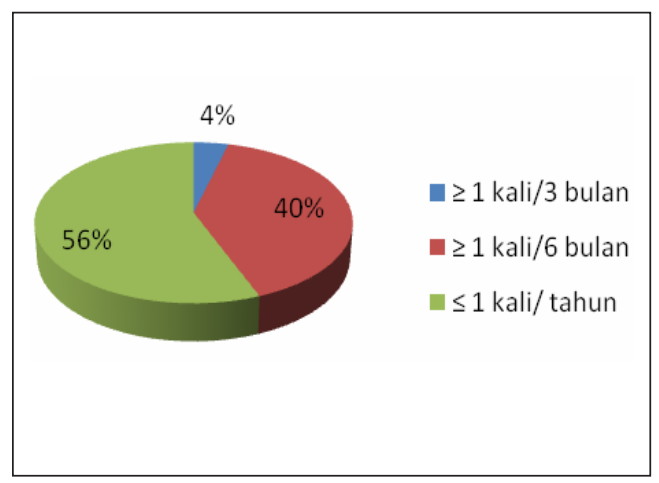

Gambar 10. Frekuensi Beli Pakaian Figure 10. Frequency of Buying Clothes

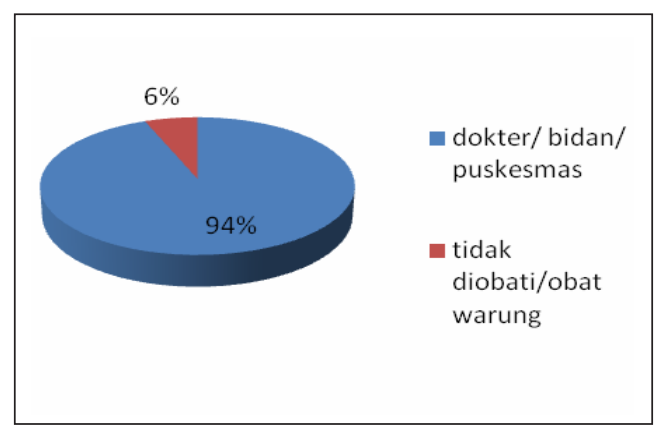

Gambar 12. Pengobatan Anggota Rumah Tangga

Figure 12. Treatment of Household Member 


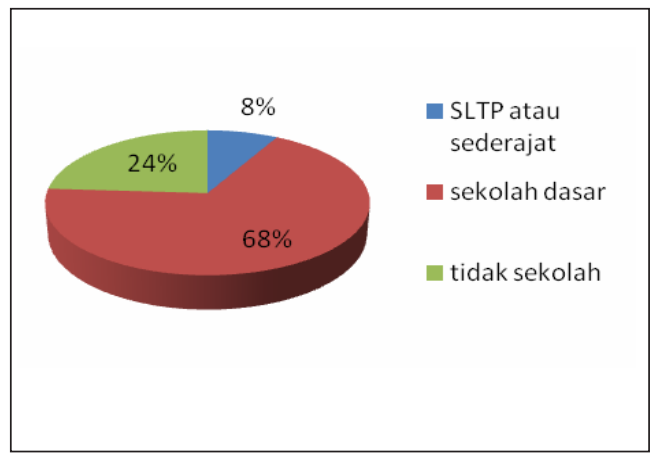

Gambar 13. Tingkat Pendidikan Kepala RT Figure 13. Education Level Household Leader

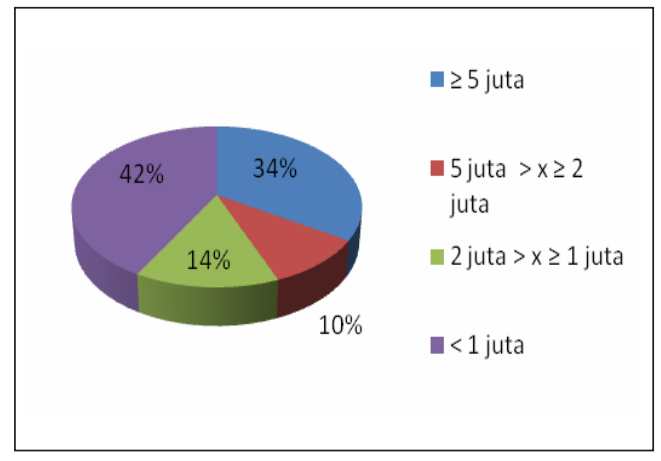

Gambar 14. Jumlah Tabungan/ Aset Berharga

Figure 13. Total Savings/Asset Securities 